\title{
Factors that Affect Effective Planning Skills of the Teacher in the Classrooms
}

\author{
Dr. Leticja Papa-Gusho \\ Pedagogy-Psychology Department, Faculty of Social Sciences, Tirana University \\ Email: Ipapagusho@yahoo.co.uk

\section{Dr. in Process Rozeta Biçaku-Çekrezi}

Department of Foreign Languages, Faculty of Education, "Aleksandër Moisiu" University, Durrës

Email: rcekrezi@yahoo.com

\section{Doi:10.5901/ajis.2015.v4n3s1p560}

\begin{abstract}
The main aim of this article is to examine the factors that affect planning skills of the teacher in the classrooms. These factors are: organizing the classroom and the teaching materials; effective implementation of lesson plans; and time management. This phenomenon is handled starting from the students' perceptions of the high schools in Tirana, Durrës and Elbasan. The approach of this study was quantitative and sample extraction is carried out through the stages sampling technique. For the data collection a Likert scale was used, with a Cronbach alpha coefficient reported, .77, .75, .62, and .65. Through the use of advanced statistical analysis there was identified a model which predicts that intervention in some variables such as, the organizing of the classroom and the teaching materials, effective implementation of lesson plans and time management improves the effective planning skills of the teacher. Results showed that there exists a positive relationship between teacher's effective planning skills and other variables, which are organizing the classrooms and the teaching material, effective implementation of lesson plans and time managements. $F(3,834)=573.630, p=.000$, adjusted $R 2=.672$.
\end{abstract}

Keywords: Teaching, planning skills, organizing the classrooms

\section{Introduction}

Classrooms with more structure have been shown to promote more appropriate academic and social behaviors, as well as greater task involvement, friendlier peer interactions, more helpful behaviors, more attentive behavior, and less aggression (Simonsen et al, 2008). Regardless of the amount of control teachers have over what and how they teach, in order to design and implement effective lessons, every teacher should have a: system for writing daily lesson plans that is easily managed, long-range plan and focused vision, method for obtaining and organizing new teaching ideas, and plan for reflection on teaching strategies and making improvements (Powell, 2009, p. 250)

Research highlights the importance of pupils always being aware of the purpose of the content of lessons, and it also shows that effective learning occurs where teachers clearly explain the objectives of the lesson at the outset, and refer to these throughout the lesson to maintain focus (Brophy \& Good, 1990 in Sammons et al, 1995). According to Brophy and Good, these objectives should be related to previous study and to things of personal relevance of the pupils.

\section{Literature Review}

\subsection{Effective planning skills}

Good teachers are flexible and respond creatively to what happens in the classroom, but they also need to have thought ahead, to have a destination which they want their students to reach, and some idea of how they are going to get there, and a plan helps to remind teachers what they intended to do (Harmer, 2007, p. 156). Creating and implementing a productive learning environment requires careful planning. According to Emmer and Evertson (2009), classroom management begins long before the students come into the classroom. Effective teachers plan their classroom management before the school year begins, and know what tasks they will need to undertake at the beginning and throughout the year (Simonsen et al, 2008).

Stronge, (2014) states that teachers should consistently plan using state and local school district curricula and 
standards, effective strategies, resources, and data to address the differentiated needs of all students. For a better instructional planning the author suggests that teachers should continually seek and use multiple data and real world resources to plan differentiated instruction to meet the individual student needs and interests in order to promote student accountability and engagement. According to Stronge (2014), some of the performance indicators are as follow, but are not limited to:

The teacher; analyzes and uses student learning data to inform planning; develops plans that are clear, logical, sequential, and integrated across the curriculum (e.g., long-term goals, lesson plans, and syllabi), plans instruction effectively for content mastery, pacing, and transitions, plans for instruction to meet the needs of all students, aligns and connects lesson objectives to state and local school district curricula and standards, and student learning needs, develops appropriate course, unit, and daily plans, and is able to adapt plans when needed (Stronge, 2014, p. 35).

\subsection{Effective implementation of lesson plans}

For an effective implementation of lesson plans, teachers should ask students questions about their previous knowledge and experience, match the activities with the set objectives, lead the students to practice the acquired knowledge, and give students the opportunity to work individually, in groups or as a whole class, according to the task being performed. Teachers should also give clear instruction to pass from one activity to another, make sure the students are able to perform what they are asked to, and make a summary of the acquired knowledge at the end of each class.

Loughran (2010) explains that the ideas, information, beliefs and attitudes that learners bring with them to the classroom are some of the elements that comprise what could be termed as their prior knowledge, or knowledge gained prior to formal teaching (p. 57).

In order to effectively implement lesson plans, teachers should have knowledge about activities, and their types. Emmer and Evertson (2009) explain that the term activity describes organized behavior that the teacher and students engage in for a common purpose (p. 88). The authors explain that typical activities in secondary classes include discussions, recitations, group work, presentations, seatwork, and checking, although this is by no means a complete list (p. 88).

Emmer and Evertson (2009) assert that a central theme in managing activities well is the idea of activity flow, the degree to which a lesson proceeds smoothly without digressions, diversions, or interruptions. Activity flow is maintained through three types of teacher behaviors: preventing misbehavior, managing lesson movement, and maintaining group focus (p. 95.)

\subsection{Organizing the classroom and the teaching material}

The first step in effective classroom management is setting up a physical classroom layout that will facilitate routines and procedure, even though this arrangement should be viewed as a work in progress that will probably be changed multiple times throughout the year as teachers should adjust things for the students' evolving needs (Powell, 2009, p. 2). How the classroom is organized and decorated can either contribute to or detract from creating a good environment for teaching and learning for students and teachers alike. Regardless of how the classroom is arranged, an atmosphere of comfort, safety, and order is a critical backdrop for effective learning (Marzano et al, 2005, p. 135). Sometimes a sitting arrangement can determine the interactivity of a classroom. In reviewing research on seating arrangements, Lambert (1995 as cited in Evertson \& Neal, 2006) concluded that seating flexibility, as opposed to a perpetually fixed seating arrangement, is a necessary prerequisite for an interactive classroom.

Research suggests that the physical environment can have an effect on both the attitudes and achievement of pupils (Sammons et al, 1995, Sprick, 2006, Simmonsen et al, 2008). It was found that the decisions made by teachers regarding environmental arrangements were driven by their philosophies about how students learn. (Evertson \& Neal, 2006). Sprick, (2006), on the other hand suggests that the physical organization of the classroom has a significant influence on student behavior. If student desks are arranged in a manner that makes it difficult for the teacher to circulate through the room, student behavior is likely to be less responsible than if the room is arranged so that the teacher can easily be among students (p. 58). Sprick offers the following suggestions regarding the physical arrangement of a classroom; a) make sure you have easy access to all parts of the room, b) arrange student desks to optimize the instructional tasks that students are mostly likely to engage in, and $c$ ) minimize the disruptions caused by high-traffic areas in the class (p. 62). 


\subsection{Time management}

Emmer and Evertson (2009), state that effective teachers, who establish an efficient management system from the beginning of the school year, will have more time to devote to student learning, than teachers who are constantly trying to use an inefficient management system, but not all time allocated to academic activities is actually spent engaged in these activities (Marzano, 2001, Brophy \& Good, 1984, Doyle, 1984).

Various studies have examined the relationship between time management behaviors and other variables such as academic achievement, stress, and creativity, and these studies have shown that time management behaviors or skills were often related to academic achievement; effective time management lower stress and strain; good time managers preferred planning and organization; older subjects and women engaged more frequently in planning and time management behaviors; and on the other hand, inefficient time use, lack of control over time demands, and inadequate amounts of time appeared to have a negative impact on individuals' psychological resources (Hellsten, 2012).

Empirical research literature indicates that student achievement is contingent upon wise use of instructional time since it affects various aspects of student learning, and in fact time management studies show that the more time you spend on advanced planning, the less total time required for the completion of the project (Burden, 1981, Emmer and Evertson, 2009). Time management principles can help teachers become more aware of ways in which time can be used to the greatest advantage. According to Burden (1981), an exploration of personal time perspectives is a step toward establishing effective patterns of behavior.

\section{Methodology}

\section{Population and sampling}

The population of this study consisted of all secondary school students in the cities of Tirana, Durres and Elbasan. Out of the total population, a sample of 1020 students was randomly selected as respondents. To ensure equality of representation, the secondary schools were selected to be private and public secondary schools, general and professional secondary schools, and lastly the schools were chosen from the suburb as well as the central areas of the cities. Of all the 1020 participants in this study $35.4 \%$ of the respondents were males and $64.6 \%$ of the respondents were females.

The instrument

The dimensions included in this paper are; effective communication with students, organizing students for effective instruction, good practices for the assessment and feedback, and effective interpersonal relationship. The questionnaire was designed based on a Five Point Likert scale; 1 - It never happens in my class, 2 - It helps me very little in knowledge acquisition, 3 - It helps me somehow in knowledge acquisition, 4 - It helps me very much in knowledge acquisition, 5 - It is one of the elements that helps me the most in knowledge acquisition.

To ensure the validity and reliability of the data collecting tool, a pilot study was conducted in three secondary schools; each one selected from each city included in the study. The questionnaire was reviewed in the light of the results gained from the pilot study. Cronbach Alpha was calculated to ensure reliability of the instrument (Tab. 1).

Table 1. Instrument reliability. Cronbach's Alpha of the dimensions included in this paper.

\begin{tabular}{|l|c|c|}
\hline Dimensions & Cronbach's Alpha & Nr of items \\
\hline Effective planning skills & .77 & 10 \\
\hline Effective implementation of lesson plans & .75 & 10 \\
\hline Organizing the classroom and the teaching material & .62 & 8 \\
\hline Time management & .65 & 7 \\
\hline
\end{tabular}

Analysis of the data

Data were collected from 1020 secondary school students using a questionnaire. The 1020 questionnaires that were personally administered by the researcher to each respondent were collected back by the researcher personally and the response rate was $100 \%$. The students who refused to complete the questionnaire are not further considered as respondents.

The data was gathered from the survey and transported into the computer statistical package SPPS, version 21. From the analyses of the dependent variable that is perception of the students for the dimension teacher's effective planning skills has result a non-normal distribution. In this case this variable is transformed into a normal distribution, to 
meet the assumption of the parametric techniques. (Pallant, 2010).

Table 2. Main question, variables, and analytic procedures

\begin{tabular}{|c|c|c|}
\hline Main question & Variables & SPSS Procedures \\
\hline $\begin{array}{l}\text { How well the three measures of students' perceptions of } \\
\text { effective implementation of lesson plans, organizing the } \\
\text { classrooms and the teaching materials and time management } \\
\text { predict the variable of the teacher's effective planning skills? }\end{array}$ & $\begin{array}{l}\text {-Effective planning skills } \\
\text {-Effective implementation of lesson plans } \\
\text {-Organizing the classroom and the } \\
\text { teaching material } \\
\text {-Time management }\end{array}$ & Multiple Regressions. \\
\hline
\end{tabular}

\section{Results and Discussion}

The findings derived from the analyses, show that $67.2 \%$ of the variance in the variable "perception of the students about teachers' effective planning skills" can be predicted from the independent variable that are, "organizing the classrooms and the teaching material", " effective implementation of lesson plans", and " time management".

Table 3. The variance of variable "perception of the students about teachers' effective planning skills

Model Summary

\begin{tabular}{|c|c|c|c|c|}
\hline Model & $\mathrm{R}$ & $\mathrm{R}$ Square & Adjusted R Square & Std. Error of the Estimate \\
\hline 1 & $.821^{\mathrm{a}}$ & .674 & .672 & .057 \\
\hline
\end{tabular}

a. Predictors: (Constant), Organizing the classroom and the teaching material, Effective implementation of lesson plans, Time management

b. Dependent Variable: Effective planning skills

The ANOVA table shows, that the overall model revealed to be statistically significant, $F(3,834)=573.630, p=.000$, adjusted $\mathrm{R}^{2}=.672$.

Table 4. Model summary to predict "Effective planning skills".

Coefficients $^{\mathrm{a}}$

\begin{tabular}{|l|c|c|c|c|c|}
\hline \multirow{2}{*}{ Model } & \multicolumn{2}{|c|}{ Unstandardized Coefficients } & Standardized Coefficients & \multirow{2}{*}{ T } & Sig. \\
\cline { 2 - 5 } & $\mathrm{B}$ & Std. Error & Beta & & \\
\hline (Constant) & 1.054 & .012 & .018 & .000 \\
Effective implementation of lesson plans & .008 & .000 & .583 & 21.148 & .000 \\
1 Time management & .004 & .001 & .213 & 7.239 & .000 \\
Organizing the classroom and the teaching material & .002 & .000 & .123 & 4.954 & .000 \\
\hline
\end{tabular}

a. Dependent Variable: Effective planning skills

Note. $\mathrm{n}=1020 R^{2}=.674$, Adjusted $R^{2}=.672, \mathrm{~F}(3,834)=573.630, \mathrm{p}=.000$

An examination of all individual predictors in Table 4 , indicates that effective implementation of lesson plans $(B=.008, p$ $=.000$ ) is a significant predictor of the teacher's effective planning skills. This suggests that a higher level of the effective implementation of lesson plans is associated with a higher level of teacher's effective planning skills. For every one unit increase in effective implementation of lesson plans score, there is a corresponding increase of .008 in score of teacher's effective planning skills. Time management $(B=.004, p=.000)$ is also a significant predictor of the teacher's effective planning skills. This suggests that a higher level of time management is associated with higher level of the teacher's effective planning skills. For every one unit increase in time management score, there is a corresponding increase of .004 in score of teacher's effective planning skills. Organizing the classroom and the teaching materials $(B=.002, p=.000)$ is a significant predictor of the teacher's effective planning skills. This suggests that a higher level of organizing the classroom and the teaching material is associated with a higher level of teacher's effective planning skills. For every one unit increase in organizing the classrooms and teaching materials score, there is a corresponding increase of .002 in score of teacher's effective planning skills.

The multiple regression equation is: 
$\hat{Y}=.008$ * effective implementation of lessons plan +.004 * time management +.002 * organizing the classrooms and teaching materials.

\section{Conlusion}

At the end of this paper, some results can be concluded. From the population of the students who attend high school in Tirana, Durrës and Elbasan a sample of 1020 students was drown through the stages sampling method. Out of 1020 students of the sample, just 361 are boys and the other 658 are girls, or $35.4 \%$ are boys and $64.6 \%$ are girls. To answer the question, how well the three measures of students' perceptions of effective implementation of lesson plans, organizing the classrooms and the teaching materials and time management predict the variable of the teacher's effective planning skills, multiple regression analysis is conducted.

From this statistical analysis it was revealed that there exists a positive relationship between students' perceptions of effective implementation of lesson plans, organizing the classrooms and the teaching materials and time management predict the variable of the teacher's effective planning skills.

More specifically, effective implementation of lesson plan $(B=.008, p=.000)$, time management $(B=.004, p=$ $.000)$ and organizing the classrooms and teaching materials $(B=.002, p=.000)$ were significant predictors of the teacher's effective planning skills.

\section{References}

Brophy, J. \& Good, TH. L. (1984). Teacher Behavior and Student Achievement. ERIC Document No. ED 251422

Burden, P. R. (1981). Time Management for Educators. ERIC Document No. ED 210250

Doyle, W. (1984). Effective Classroom Practices for Secondary Schools. ERIC Document No. ED 261052.

Emmer, E. T \& Evertson, C. M. (2009). Classroom management for middle and high school teachers. $8^{\text {th }}$. Ed. Pearson Education. USA.

Evertson, C. M., \& Neal, K. W. (2006). Looking into Learning-Centered Classroom Implications for Classroom Management. National Education Association. ERIC Document No. ED 495820

Harmer, J. (2007), How to teach English. New Edition. Pearson Education Limited. England.

Hellsten, L. M. (2012). What Do We Know About Time Management? A Review of the Literature and a Psychometric Critique of Instruments Assessing Time Management, Time Management. Retrieved from: http://www.intechopen.com/books

Loughran, J. (2010). What expert teachers do? Enhancing professional knowledge for classroom practice. Allen \& Unwin. Australia

Marzano, R. J. (2001). A New Era of School Reform: Going Where the Research Takes Us. Eric Document No. ED 454255

Marzano, R. J., Gaddy, B. B., Foseid, M. C., Foseid, M. P., \& Marzano, J. S. (2005). A Handbook for Classroom Management that Works. Alexandria, Va. Association for Supervision and Curriculum Development.

Powell, A. (2009). The Cornerstone: Classroom Management That Makes Teaching More Effective, Efficient, and Enjoyable. Due Season Press. U.S.A.

Sammons P., Hillman, J. \& Mortimore, P. (1995). Key Characteristics of Effective Schools: A Review of School Effectivenes Research. ERIC Document No. ED 389826

Simonsen et al. (2008). Evidence-based Practices in Classroom Management: Considerations for Research to Practice1. Education and Treatment of Children, Volume 31, Number 3, pp. 351-380. West Virginia University Press

Sprick, R. S. (2006). Discipline in the Secondary Classroom. Second Edition. Jossey-Bass. U.S.

Stronge, J. (2014). Teacher Key Effectiveness System Handbook. Georgia Department of Education. Retrieved from http://www.gadoe.org/School-Improvement/Teacher-and-Leader-Effectiveness/Pages/Teacher-Keys-Effectiveness-System.aspx 